\title{
25TH ANNIVERSARY EDITION
}

RAMUS

CRITICAL STUDIES IN GREEK AND ROMAN LITERATURE

Vol. 25 No. 1

1996 


\title{
Books Published by Aureal Publications
}

\author{
- in the Ramus Monographs series:
}

\author{
Existentlalism and Euripides: Sickness, Tragedy and Divinity in the Medea, the Hippolytus \\ and the Bacchae, by W. Sale (Ramus Monographs 1, 1977).
}

An examination of what are probably Euripides' three best known plays in the light of theories developed in existential psychoanalysis. This is a proloundly humane study that brings out Euripides' insight into the psychology of human beings and into the gods and demons with which they people their world.

Paper, 142pp. ISBN $0949916013 \quad$ A\$24.00 (recommended)

Horace's Lyric Poetry: The Force of Humour, by Peter Connor (Ramus Monographs 2, 1987).

The author sees humour in Horace as 'a positive force of, and in, his engagement with the several ideas and attitudes he explores'. Far from being peripheral or tangential, humour functions as an integral element in the Odes; this analysis of its place in the total experience of reading these poems significantly enhances our perception of the quality of Horace's achievement.

Paper, 221pp.

ISBN 0949916072

A $\$ 24.00$ (recommended)

Tragic Aporia: A Study of Euripides' Iphigenia at Aulis, by C.A.E. Luschnig (Ramus Monographs 3. 1988).

The self-consciously literary nature of this tragedy is well brought out in this study. Aporia in its widest sense. the guil that exists between myth and reality, is shown to be the unifying element in the play; the only way to bridge this gulf is through the medium of art. Iphigenia's choice, which sets up an ending as startling as any in Euripides, is revealed as ultimately an aesthetic one.

Paper, 130pp.

ISBN 0949916099

A\$24.00 (recommended)

\section{- book versions of special Ramus issues:}

Ancient Pastoral: Ramus Essays on Greek and Roman Pastoral Poetry, edited by A.J. Boyle.

This volume contains the seven specially commissioned essays on Theocritus, Virgil and Calpurnius Sicilus which first appeared in Ramus Vol. 4 no. 2 (1975). All the contributors are specialists in the field of classical pastoral.

Paper, 148pp.

ISBN 0949916005

A $\$ 24.00$ (recommended)

Virgil's Ascraean Song: Ramus Essays on the Georgics, edited by A.J. Boyle.

A publication in book form of the special number of Ramus (Vol. 8 no. 1, 1979) devoted to the Georgics. As well as seven essays by distinguished scholars in the field, this volume incorporates an introduction and an index of passages cited.

Paper, 124pp.

ISBN 0949916021

A $\$ 24.00$ (recommended) 


\section{RAMUS}




\title{
RAMUS
}

\section{CRITICAL STUDIES IN GREEK AND ROMAN LITERATURE}

\author{
EDITED BY \\ A.J. BOYLE \\ ASSOCIATE EDITOR \\ J.L. PENWILL
}

Vol. 25 No 1

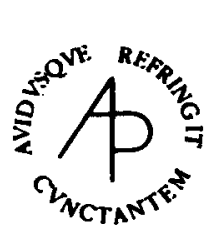

1996 


\section{RAMUS \\ CRITICAL STUDIES IN GREEK AND ROMAN LITERATURE}

Editor:

A.J. Boyle, Department of Classics, University of Southern California, Los Angeles, California 90089-0352, USA.

Associate Editor and Business Manager:

J.L. Penwill, School of Arts, La Trobe University Bendigo, P O Box 199, Bendigo, Victoria, Australia 3550. E-mail: J.Penwill@bendigo.latrobe.edu.au

Publishers:

Aureal Publications, P O Box 49, Bendigo North, Victoria, Australia 3550. (Registered Office: 250 Holdsworth Rd, Bendigo, Vic. 3550.)

Printers:

Printed in Australia by Australian Print Group, 76 Nelson St, Maryborough, Vic. 3465.

\section{Subscription:}

Per annum: Full-time students A $\$ 20.00$ (US\$18.50); other individuals A $\$ 32.50$ (US\$29.80); school libraries A $\$ 34.00$ (US\$31.00); other libraries and institutions A $\$ 46.50$ (US\$40.00). Subscribers receive two issues of Ramus per annum. Price per singie issue is $60 \%$ of the appropriate annual subscription price. Postage, packing and bank charges are included in these prices. Payment should be made out to Aureal Publications and sent to the publishers, to whom all orders and enquiries should be addressed.

All back numbers are available and may be ordered from the publishers. Substantial discounts apply on orders for three or more volumes within the backfile.

Advice to potential contributors:

The language of publication is English. Quotations in Latin and Greek must be accompanied by a translation, except where the quotation consists of a word or short phrase the meaning of which is made clear by the context. Submissions should be typed in double spacing and supplied both in hard copy and on disk (WordPerfect 5.1 or Microsoft Word 5.0 preferred). The text of the hard copy should contain no indication of the identity of the author. Please direct submissions to the Editor at the address given above; note, however, that no responsibility is accepted for unsolicited material.

To avoid delays in publication the proofreading will normally be done by the editors.

THIS PUBLICATION IS COPYRIGHT. APART FROM FAIR DEALING FOR THE PURPOSES OF RESEARCH, STUDY, CRITICISM OR REVIEW OR COPYING BY EDUCATIONAL IN STITUTIONS UNDER STATUTORY LICENCE AS DEFINED IN THE COPYRIGHT ACT 1968 AS AMENDED, NO PART MAY BE REPRODUCED BY ANY MEANS WITHOUT WRITTEN PERMISSION 


\section{CONTENTS}

EDITORIAL: RAMUS 25

page vii

EUROPE'S MALLEABLE TOPOS: MYTHOLOGISING ANCIENT GREECE

Gerald Fitzgerald

CALLIMACHUS SWINGS (FRR. 178 AND 43 PF.)

Richard Hunter

HORACE'S ARBOREAL ANNIVERSARY (C. 3.8)

Michael C.J. Putnam

OUT OF CIRCULATION? AN ESSAY ON EXCHANGE IN PERSIUS' SATIRES

Martha Malamud

LUCAN'S LEGENDS OF THE FALL

Andrew D. Walker 